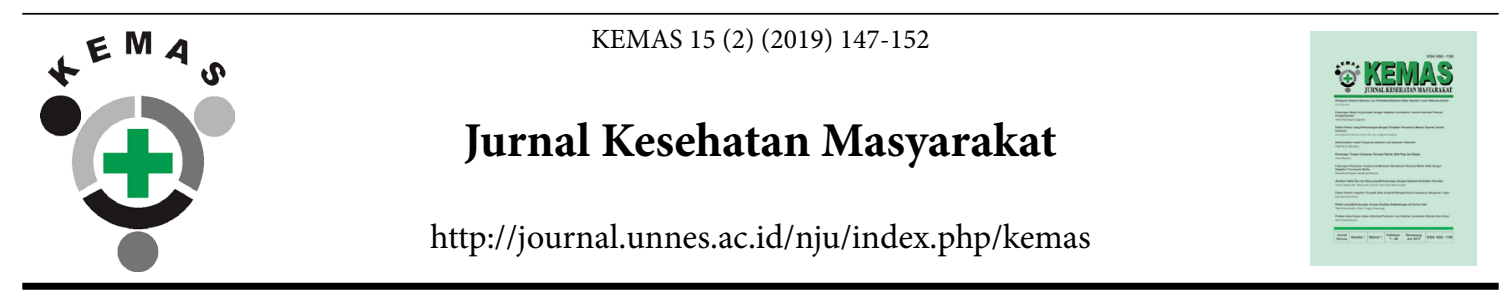

\title{
Hypertension and Diabetes Mellitus Increase the Risk of Stroke
}

\author{
Liena Sofiana ${ }^{\bowtie}$, Dwy Desy Rahmawati \\ Faculty of Public Health, Universitas Ahmad Dahlan
}

\section{Article Info \\ Article History: \\ Submitted May 2018 \\ Accepted October 2019 \\ Published November 2019 \\ Keywords: \\ Hypertension, Stroke, \\ Diabetes Mellitus \\ DOI \\ https://doi.org/10.15294/ \\ kemas.v15i2.14349}

\begin{abstract}
Stroke is one of the cause of death and major neurological disability in Indonesia. The risk of stroke increases with the number of risk factors. Stroke is the main cause of inpatient death at Panembahan Senopati General Hospital in Bantul. The independent variables in this study were hypertension and diabetes mellitus. This study aim to determine the relationship of hypertension and diabetes mellitus to the incidence of stroke. The study was conducted in 2016 and was an observational analytic study with cross sectional design. The number of respondents were 256 samples, where samples were taken by simple random sampling. The research instrument is observation sheet of medical records. Analysis of data was conducted using univariate and bivariate analysis using chisquare test. Bivariate analysis showed significant correlation statistically and biologically between hypertension $(\mathrm{RP}=9.000 ; \mathrm{CI}=4.866-16.645 ; \mathrm{p}$ value $=0.000)$ and diabetes mellitus $(\mathrm{RP}=4.226 ; \mathrm{CI}=3.089-5.780 ; \mathrm{p}$ value $=0.000)$ with the incidence of stroke. Efforts to increase health promotion program to improve community awareness regarding the incidence of stroke are suggested to improve the quality of life of stroke patients.
\end{abstract}

\section{Introduction}

According to WHO, stroke is a disease caused by the sudden cessation of blood flow that supplies the brain, either because of the blood blockage or rupture of blood vessels. This condition deprives the affected brain tissue of oxygen and nutrients and cause damage (WHO, 2010). Stroke is a cerebrovascular disease that is found not only in developed countries but in developing countries. Stroke is the second most common cause of death throughout the world and is a major cause of serious long-term disability in adults, resulting in $90 \%$ of patients experiencing a residual deficit ( Celin AT, Seuma J, \& Ramesh A, 2012).

According to the WHO (World Health Organization), $51 \%$ of deaths from stroke worldwide are caused by high blood pressure. In addition, an estimated $16 \%$ of stroke deaths are caused by high blood glucose level (WHO, 2010). Metabolic syndrome in respondents could trigger a stroke. Metabolic syndrome is a risk factor for stroke and includes: high blood pressure, increased blood sugar, obesity and dyslipidemia. Further analysis showed that the main determinants of stroke at this baseline data include hypertension, diabetes mellitus, coronary heart disease and low economic status. The main determinants of stroke are hypertension and diabetes mellitus. Among those with hypertension, $28 \%$ had stroke. In comparison, among those without hypertension only $9.3 \%$ suffered stroke. Similarly, among people with diabetes mellitus $8 \%$ had a stroke, 
while in those without DM only $2 \%$ suffered stroke ( Riyadina \& Rahajeng, 2013).

The high blood sugar levels in the body pathologically play a role in increasing the concentration of glycoprotein, which is the originator of several vascular diseases. High blood glucose levels at the time of stroke will increase the likelihood of expansion of the infarct area because of formation of lactic acid due to anaerobic glucose metabolism which damages brain tissue (Ramadany, Pujarini, \& Candrasari, 2013). Stroke reduces the quality of life, work productivity, and participation in social life due to high lost productive time secondary to the disability from a stroke. The number of strokes in young patients is not as prevalent as in elderly patients but young patients will suffer longer stroke complications which increases morbidity in stroke patients (Rutten-jacobs et al., 2011). The efforts that can be made to prevent the occurrence of stroke is to reduce the risk factors. Disability and death caused by stroke can be prevented by strengthening control efforts and reducing the burden caused by stroke.

Based on the health profile of the province in Yogyakarta in 2012, heart disease and stroke in the last ten years were always among the 10 highest cause of death. Degenerative diseases in Bantul Regency continue to increase, doubling the burden of health in Bantul Regency. In addition to handling infectious diseases, preventive measures to increase non-communicable diseases must also be implemented and intensified. Based on data from the DIY Health Office in 2009, the incidence of non-communicable diseases, such as hypertension $(17.43 \%)$ and diabetes mellitus (10.32\%) began to dominate outpatients setting.

The main cause of death for all age groups in hospitalized patients at Panembahan Senopati Hospital in Bantul in 2009 was stroke (17.84\%). This figure shows that degenerative diseases have become a serious problem besides infectious diseases. Based on a preliminary study conducted in May at Panembahan Senopati Hospital in Bantul, the total number of neurology clinic visits in 2015 were 12,930 visits and in outpatients in 2015 there were 344 patients diagnosed with stroke and the factors that contributed to the stroke events were hypertension. The importance of this study is to determine the effect of hypertension and diabetes mellitus with the incidence of stroke so that prevention can be carried out to reduce the incidence of stroke. Until present, no study has been conducted on the relationship between hypertension and diabetes mellitus with the incidence of stroke in Panembahan Senopati General Hospital Bantul. Therefore, we were interested in conducting the study at Panembahan Senopati General Hospital Bantul. Method

This is an observational analytic study, with a cross-sectional study design in which each subject of the study will only be assessed regarding character status or variable at the same time. This design was chosen because it was in accordance with the purpose of the study, namely to find the relationship between the independent variable to the dependent variable. This study was carried out at Panembahan Senopati General Hospital Bantul, from August to September 2016. The population in this study was 1036 patients who was treated at the neurology clinic at Panembahan Senopati General Hospital. We obtained a total sample of 256 patients using simple random sampling. Data analysis used was univariate and bivariate analysis. Bivariate analysis was tested by chisquare with significance level of $<0.05$.

\section{Results and Discussion}

The characteristics of respondents in this study include age, gender, hypertension status and diabetes mellitus is presented in table 1 .

The majority of respondents are $\geq 50$ years old, and this group 69 respondents (26.4\%) had stroke. This is in line with research stated that most of high risk of stroke generally happened on person aged $>55$ years old and it is stated that there is a relationship between age and the incidence of stroke. Increase in stroke frequency based on age was associated with aging process, where all body organs including brain blood vessels experience deterioration (Muhrini, Ika, Sihombing, \& Hamra, 2013).

The majority of the patients were male and 49 was affected by stroke (19.1\%). This is supported by previous research, that most stroke patients are male, amounting to 90 people (65.69\%) (Erawantini \& Roro Lia Chairina, 2016). The older a male person with 
Table 1. Frequency distribution based on age, sex, stroke, hypertension, and diabetes mellitus.

\begin{tabular}{lllll}
\hline Respondent Characteristics & Stroke & \multicolumn{3}{l}{ No stroke } \\
\cline { 2 - 5 } & $\mathrm{n}$ & $\%$ & $\mathrm{n}$ & $\%$ \\
\hline Age & 69 & 26.4 & 70 & 27.3 \\
$\geq 50$ years old & 11 & 4.3 & 106 & 41.4 \\
$<50$ years old & & & & \\
Sex & 49 & 19.1 & 88 & 34.3 \\
Male & 31 & 12.1 & 88 & 34.3 \\
Female & & & & \\
Hypertension & 70 & 27.3 & 42 & 16.4 \\
Hypertension & 10 & 3.9 & 134 & 52.3 \\
No Hypertension & & & & \\
Diabetes Mellitus & 41 & 16.0 & 10 & 3.9 \\
Diabetes Mellitus & 39 & 15.2 & 166 & 64.8 \\
No Diabetes Mellitus & 80 & 31.2 & 176 & 68.8 \\
Total & & &
\end{tabular}

Source: Primary Data (2016)

Table 2. The relations of hypertension and diabetes mellitus on stroke

\begin{tabular}{|c|c|c|c|c|c|c|c|c|}
\hline \multirow{3}{*}{ Variables } & \multicolumn{4}{|c|}{ Stroke Occurence } & \multirow{2}{*}{\multicolumn{2}{|c|}{ Total }} & \multirow{3}{*}{ RP (CI 95\%) } & \multirow{3}{*}{$\begin{array}{l}P \\
\text { value }\end{array}$} \\
\hline & \multicolumn{2}{|c|}{ Yes } & \multicolumn{2}{|l|}{ No } & & & & \\
\hline & $\mathrm{n}$ & $\%$ & $\mathrm{n}$ & $\%$ & $\mathrm{n}$ & $\%$ & & \\
\hline \multicolumn{9}{|c|}{ Hypertension } \\
\hline Yes & 70 & 87.5 & 42 & 23.9 & 112 & 43.8 & \multirow{2}{*}{$\begin{array}{l}9.000 \\
(4.866-16.645)\end{array}$} & \multirow[t]{2}{*}{0.000} \\
\hline No & 10 & 12.5 & 134 & 76.1 & 144 & 56.3 & & \\
\hline \multicolumn{9}{|c|}{ Diabetes Mellitus } \\
\hline Yes & 41 & 51.2 & 10 & 5.7 & 51 & 19.9 & \multirow{3}{*}{$\begin{array}{l}4.226 \\
(3.089-5.780)\end{array}$} & \multirow[t]{3}{*}{0.000} \\
\hline No & 39 & 48.8 & 166 & 94.3 & 205 & 80.1 & & \\
\hline Total & 80 & 100 & 176 & 100 & 256 & 100 & & \\
\hline
\end{tabular}

Source: Primary Data (2016)

a history of hypertension and diabetes mellitus, the higher the risk of stroke. The results of bivariate analysis between hypertension and diabetes mellitus with the incidence of stroke can be seen in table 2 , the following:

Table 2 shows $\mathrm{P}$ Value $=0.000(\mathrm{p}<0.05)$ which shoes a significance relationship between hypertension and stroke. Biologically significant relationship was found where Ratio Prevalence (RP) which is equal to 9,000 , which means that respondents who have hypertension are likely to have a stroke 9,000 times greater than respondents who do not have hypertension. Confident Interval does not cover the number 1
$(4,866-16,645)$, meaning there is a relationship between hypertension and stroke. Based on the results of bivariate analysis it can be stated that the results of this study are statistically and biologically significant.

Based on the analysis of hypertension with stroke in Panembahan Senopati General Hospital Bantul, it was found that $\mathrm{p}$ value $<0.05$ and Confident Interval (CI) did not include 1 , so it can be concluded that there is a statistical significance between stroke and hypertension in Panembahan Senopati General Hospital Bantul. Respondents with a history of hypertension and stroke were greater than 
those without stroke as seen in table 2 with a percentage of $87.5 \%$. Abnormal and continuous increase in blood pressure, or commonly called hypertension, causes damage to wall arteries or wounds that encourage the deposition of plaques in the arteries and cause interference with blood flow to the brain so that it can cause blockages or rupture of blood vessels in the brain and cause strokes.

The results of this study are in accordance with the results of previous studies which stated that there was a positive and significant relationship between hypertension and stroke in Indramayu General Hospital (Saefulloh, 2016). The higher the blood pressure, the higher the likelihood of a stroke either hemorrhagic or ischemic. Hypertension is the main cause of stroke, due to abnormal blood pressure resulting in damage to blood vessel endothelial cells that cause injury and vascular cavity so it will trigger thrombosis and eventually atherosclerosis which makes blood vessels narrow so that the blood supply to the brain decreases resulting in damaged neuron cells in the central nervous system, or a stroke (Hafid, 2014). Physiological disorders that occur in patients with hypertension who do not receive rapid and well-controlled treatment increases risk for stroke (Yonata, Satria, \& Pratama, 2016). Adherence to treatment has a significant relationship with the degree of systole and diastole (Dirhan, 2012). Control of hypertension can prevent strokes.

There were more stroke patients with hypertension (65.4\%) compared to stroke patients without hypertension (34.6\%) (Kabi, Tumewah, \& Kembuan, 2015). Most patients who had their first stroke have hypertension or high blood pressure. Higher blood pressure lead to greater risk of stroke. Hypertension is a strong risk factor for stroke. This is because hypertension can dilute the walls of blood vessels and damage the inside of blood vessels and encourage the formation of atherosclerotic plaques which facilitate the occurrence of blockages or bleeding of the brain (Harrigan, Deveikis, \& Ardelt, 2009). One trigger of hypertension is stress which will tend to cause severe hypertension and it is explained that there is a relationship between stress and hypertension. The proportion of stress in hypertensive patients is $67.4 \%$ (Korneliani \& Meida, 2013) (Korneliani, Kiki and Meida, Dida 2013).

The variable diabetes mellitus in table 2 shows $\mathrm{P}$ Value $=0.000(\mathrm{p}<0.05)$, so there is a statistically significant correlation between Diabetes mellitus and stroke. Biologically significant relationship was found because Ratio Prevalence (RP) which is equal to 4,226 , which means that respondents who have diabetes mellitus are likely to have a stroke 4,226 times greater than respondents who do not have Diabetes mellitus. Confident Interval does not include number $1(3,089-5,780)$, meaning there is a relationship between Diabetes mellitus and stroke. Based on the results of bivariate analysis, it can be stated that the results of this study are statistically and biologically significant. Diabetes mellitus is a risk factor for stroke events in Panembahan Senopati General Hospital Bantul in 2015.

Based on the analysis of diabetes mellitus with stroke in Panembahan Senopati Hospital Bantul, it was found that $\mathrm{p}$ value $<0.05$ and Confident Interval (CI) did not cover the number 1, so it can be concluded that there is a statistical significance between Diabetes mellitus and stroke in Panembahan Senopati General Hospital Bantul. Diabetes mellitus is a risk factor for stroke events in Panembahan Senopati General Hospital Bantul in 2015.

High blood sugar levels cause interference with the lipid profile, allowing bad cholesterol to accumulate easily in the blood vessel walls. This results in accumulation of fat and impaired flexibility in the walls of blood vessels which causes disruption of blood flow to the brain. If the supply of oxygen and nutrients to the brain was not fulfilled, damage or death of brain cells, or stroke, ensues. Diabetes mellitus is associated with ischemic stroke where excessive blood glucose levels will disrupt the elasticity of blood vessels and the process of atherosclerosis dominates the occurrence of an embolism that will clog and become an ischemic stroke if it is affected in the brain (Ramadany et al., 2013).

People with diabetes have an increased susceptibility to atherosclerosis and an increased prevalence of atherogenic risk factors, especially hypertension, obesity, and abnormal blood lipids. The case control study of stroke 
patients and prospective epidemiological studies has confirmed that the independent effects of diabetes with the relative risk of ischemic stroke in people with diabetes from 1.8 to 3.0 (Sacco et al., 1997).

Diabetes mellitus is a risk factor for stroke in South Solok District Hospital (Dinata, Safrita, \& Sastri, 2013). Most patients have risk factors for increased blood sugar levels (60.6\%). In patients with diabetes mellitus, the risk of stroke increases two-fold compared to people without diabetes mellitus (Harsono, 2005). A person with history of diabetes mellitus has a 1.10 times greater risk to suffer a stroke compared to people who do not have a history of diabetes mellitus (Voetsch, Benke, Damasceno, Siqueira, \& Loscalzo, 2002). Diabetes mellitus causes stroke through its ability to thicken large brain blood vessels. Thickening will cause the diameter of the blood vessels to shrink, which eventually causes disruption of blood flow to the brain which leads to the death of brain cells (Permatasari, 2011).

In the non-ischemic stroke group there were 26 patients who suffered from Diabetes mellitus but were not affected by an ischemic stroke. It is recommended to lead healthy lifestyles such as not smoking, eating fruit, reducing fatty foods and doing routine physical activities at least to walk several hours every day (Ramadany et al., 2013). Walking can reduce blood glucose levels in patients with diabetes mellitus, this is because it can increase glucose uptake by muscles compared to liver glucose release during activities (Fauzi, 2013). Hyperglycemia in acute phase stroke patients can be used as a sign of diabetes mellitus and will aggravate the degree of neurological deficits and increase mortality so that stroke patients are given insulin therapy as a control (Indiyarti, 2003).

\section{Conclusions}

Based on the results of the research conducted at Panembahan Senopati General Hospital Bantul, it was shown that there was a relationship between hypertension and Diabetes mellitus with the incidence of stroke. Improvement in health promotion programs to increase public awareness related to the incidence of stroke in order to improve the quality of life of stroke patients and non-stroke patients is suggested. Implementation of a healthy lifestyle by keeping the body healthy by controlling food intake and exercising a lot is encouraged, as well as routinely checking blood pressure and blood sugar levels. Future researchers are expected to examine other risk factors related to stroke events such as heart disease, stress, smoking, consuming alcohol, lack of physical activity, and other factors associated with stroke.

\section{References}

Celin AT, Seuma J, \& Ramesh A. (2012). Assessment of Drug Related Problems in Stroke Patients Admitted to a South Indian Tertiary Care Teaching Hospital. Indian Journal of Pharmacy Practice, 5(4), 28-33.

Dinata, C. A., Safrita, Y., \& Sastri, S. (2013). Gambaran Faktor Risiko dan Tipe Stroke pada Pasien Rawat Inap di Bagian Penyakit Dalam RSUD Kabupaten Solok Selatan Periode 1 Januari 2010 - 31 Juni 2012. Jurnal Kesehatan Andalas, 2(2), 57-61.

Dirhan. (2012). Hubungan Pengetahuan, Sikap Dan Ketaatan Berobat Dengan Derajat Sistole Dan Diastole Pasien Hipertensi. Jurnal Ilmiah Farmasi, 9(1).

Erawantini, F., \& Roro Lia Chairina, R. (2016). Analisis Faktor Risiko Stroke Berdasarkan Telaah Berkas Rekam Medis Periode 2015 di RS Jember Klinik. Prosiding Seminar Hasil Penelitian Dan Pengabdian Masyarakat Dana BOPTN Tahun 2016, 11-16.

Fauzi, L. (2013). Jurnal Kesehatan Masyarakat. Jurnal Kesehatan Masyarakat, 8(2), 106-112.

Hafid, M. A. (2014). Hubungan Riwayat Hipertensi dengan Kejadian Stroke Di RSUP Dr. Wahidin Sudirohusodo Makassar 2012. Jurnal Kesehatan, VII(1), 6.

Harrigan, M. R., Deveikis, J. P., \& Ardelt, A. A. (2009). Handbook of Cerebrovasculer Disease and Neurointerventional Technique. Humana Press.

Harsono. (2005). Buku Ajar Neurologi Klinis. Yogyakarta: Gadjah Mada University Press.

Indiyarti, R. (2003). Dampak hiperglikemia terhadap kelangsungan hidup penderita stroke. Jurnal Kedokteran Trisakti, 22(3), 105-109.

Kabi, G. Y. C. R., Tumewah, R., \& Kembuan, M. A. H. N. (2015). Gambaran Faktor Risiko pada Penderita Stroke Iskemik pada Usia Dewasa Muda. E-Clinic (ECI), 3(1), 1-6.

Korneliani, K., \& Meida, D. (2013). Hubungan obesitas dan stres dengan hipertensi guru sd wanita. Jurnal Kesehatan Masyarakat, 8(2), 113-120. 
Muhrini, A., Ika, S., Sihombing, Y., \& Hamra, Y. (2013). dengan Kejadian Stroke. Medula, $1(1), 24-30$.

Permatasari. (2011). Kejadian Hiperkolesterolemia Disertai Hipertensi dan Diabetes mellitus Pada Penderita Stroke Trombotik Akut. Bulletin Penelitian, 13(3), 112-120.

Ramadany, A. F., Pujarini, L. A., \& Candrasari, A. (2013). Hubungan Diabetes Melitus dengan Kejadian Stroke Iskemik Di RSUD DR . Moewardi Surakarta Tahun 2010. Biomedika, 6(2), 11-16.

Riyadina, W., \& Rahajeng, E. (2013). Determinan Penyakit Stroke. Artikel Penelitian, 7(7), 324-330.

Rutten-jacobs, L. C. A., Maaijwee, N. A. M., Arntz, R. M., Alebeek, M. E. Van, Schaapsmeerders, P., Schoonderwaldt, H. C., ... Norris, D. G. (2011). Risk factors and prognosis of young stroke. The FUTURE study: A prospective cohort study . Study rationale and protocol. BMC Neorology, 11(109), 1-8.

Sacco, R. L., Benjamin, E. J., Broderick, J. P., Dyken, M., Easton, J. D., Feinberg, W. M., ... Wolf, P. A. (1997). Risk Factors. Stroke, 28(7), 15071517.

Saefulloh, M. (2016). Analisis faktor yang berhubungan dengan kejadian stroke di rsud indramayu 12 . Jurnal Pendidikan Keperawatan Indonesia, 2(2), 65-76.

Voetsch, B., Benke, K. S., Damasceno, B. P., Siqueira, L. H., \& Loscalzo, J. (2002). Paraoxonase 192 Gln--\&gt;Arg polymorphism: an independent risk factor for nonfatal arterial ischemic stroke among young adults. Stroke, 33(6), 1459-1464.

Yonata, A., Satria, A., \& Pratama, P. (2016). Hipertensi sebagai Faktor Pencetus Terjadinya Stroke. Majotiry, 5(3), 17-21. 